\title{
A novel highly effective of $\beta$-mannanase producer on base Ogataea haglerorum yeast
}

\author{
Lazareva M.N. ${ }^{1}{ }^{2 *}$, Lapteva A.R. ${ }^{2}$, Tarutina M.G. ${ }^{1,2}$, Sineoky S.P. ${ }^{2}$ \\ ${ }^{1}$ NRC «Kurchatov Institute»- GOSNIIGENETIKA, Kurchatov Genomic Center, NRC «Kurchatov Institute», Moscow, Russia \\ ${ }^{2} N R C$ «Kurchatov Institute», Moscow, Russia \\ *e-mail: mari-mari.lm@yandex.ru
}

Key words: Ogataea haglerorum, producer, recombinant $\beta$-mannanase

Motivation and Aim: $\beta$-mannanases are enzymes of industrial applications and use in feed, food, pulp and paper industries, pharmacology and the production of detergents. $\beta$-mannanase (E.C.3.2.1.78) catalyzes the cleavage of internal $\beta$-1,4-glycoside bonds in the main polymer chain of the mannan molecule [1]. Requirements for enzyme properties vary depending on the field of application, but the most important criterion is the high specific activity of the enzyme, which is characteristic of some $\beta$-mannanases from Bacillus [2]. $\beta$-mannanase enzyme preparations are supplied to the Russian market by foreign companies. The development of highly effective domestic strains producing $\beta$-mannanase is an important goal to solve the problem of import substitution.

Methods and Algorithms: For the first time, thermotolerant methylotrophic yeast Ogataea haglerorum was used to construct the producer. To transform $O$. haglerorum yeast, an expression cassette was constructed containing, under the control of the $M O X$ promoter, a synthetic MANS gene encoding an enzyme identical to $97.4 \% \beta$-mannanases from $B$. subtilis MAFIC-S11 and B. subtilis WL-7 by BLAST.

Results: Using genetic engineering and selection methods, a stable highly productive strain of O. haglerorum, a $\beta$-mannanase producer, was obtained. Strain is characterized by high ability to express and secrete recombinant $\beta$-mannanase at temperature $37{ }^{\circ} \mathrm{C}$ under induction conditions. Strain produces about $1.0 \mathrm{mg} / \mathrm{ml}$ of enzyme when cultured in tubes; activity of $\beta$-mannanase is 14400 units $/ \mathrm{ml}$. The results of the work were included in the application for the patent of the Russian Federation: RU 2020120291 from 18.06.2020.

Conclusion: The resulting strain in its biotechnological parameters is comparable to the best foreign yeast strains - producers of $\beta$-mannanase. The properties of the ManS allow it to be used as an effective additive in animal feed industry.

Acknowledgements: Supported by the Ministry of Science and Higher Education of the Russian Federation (Grant No. 075-15-2019-1658), and was performed using the resources of the Bioresource Center - AllRussian Collection of Industrial Microorganisms.

\section{References}

1. Moreira L.R.S., Filho E.X.F. An overview of mannan structure and mannan - degrading enzyme systems. Appl Microbiol Biotechnol. 2008;79:165-178.

2. Chauhan P.S. et al. An overview of purification strategies for microbial mannanases. Int J Pharm Bio Sci. 2014;5(1):176192. 